\title{
Credit Relaxation Policy During Covid-19 Reviewed from the Force Majeure Aspect
}

\author{
Faisal Santiago \\ Universitas Borobudur, Jakarta Indonesia \\ \{faisalsantiago@borobudur.ac.id\}
}

\begin{abstract}
In the Coronavirus disease 2019 (Covid-19) situation that hit Indonesia, it had an impact on the economy and disrupted the liquidity of banks and other financial institutions. Micro, small and medium enterprises, who have an obligation for the credit they have taken, which have an impact either directly or indirectly on the performance and capacity of the debtor in fulfilling credit or financing payment obligations. The formulation of the research problem: Did the relaxation of credit provided by banks during the Covid 19 pandemic not deviate from the force majeure aspect? The findings of the research on the credit restructuring policy have deviated from the legal aspects contained in Article 1245 of the Civil Code regarding force majeure. In conducting credit restructuring, it is necessary to have deliberations between creditors and debtors, in order to realize the principle of balance and not to deviate from the force majeure aspects contained in Article 1245 of the Civil Code.
\end{abstract}

Keywords: Credit Relaxation; Force Majeure

\section{Introduction}

Indonesia is in the current situation of Coronavirus disease 2019 (Covid-19), various policies have been taken by the government to reduce its spread, such as campaigning for clean and healthy living habits, distributing masks, handsanitizers, spraying disinfectants to public places and vehicles to gradually announce physical distancing by work from home, learn from home and worship from home, and enforce PSBB in all regions in Indonesia. Limitation of interaction and the impact of the economic slowdown in the financial / banking sector. The existence of this pandemic has seriously hit economic actors and jobs have also been affected. The cessation of activities due to the impact of the Covid-19 pandemic, of course, made the public anxious in taking action, so that the impact on income was reduced.

Micro, small and medium enterprises, who have an obligation for the credit they have taken, which have an impact either directly or indirectly on the performance and capacity of the debtor in fulfilling credit or financing payment obligations. Of course, the ability to pay installments / obligations is hampered, thus disrupting the liquidity of banks and other financial institutions. Banks in their business activities besides collecting funds from the public in the form of deposits also channel them to the public in the form of credit. In the condition of Covid-19, it also had an impact on the banking world, especially regarding the problem of returning credit funds that had been allocated to customers. 
The banking industry faces challenges during the corona virus pandemic which makes it increasingly difficult and careful for banks to channel loans and maintain their collectability. However, the government's and the authorities' consolidated push has begun to show its results since 2019.

In order to maintain economic growth, the government provides a stimulus so that the economy can move again, with the issuance of Government Regulation in Lieu of Law (Perppu) Number 12020 concerning State Financial Policy and Financial System Stability for Handling the Covid-19 Pandemic, in order to face dangerous threats national economy or financial system stability. One of the policies in the financial / banking sector taken by the government is the relaxation policy. This policy was announced by President Joko Widodo on March 31, 2020 at the Bogor Palace. This policy is formally regulated through the Financial Services Authority Regulation Number 11 /POJK.03/2020 concerning National Economic Stimulus as a Countercyclical Policy on the Impact of the Spread of Coronavirus Disease 2019, which aims to encourage optimization of banking performance, especially the intermediation function, maintain financial system stability and support growth economic stimulus policy needs to be taken as a countercyclical impact of the spread of the coronavirus disease 2019 (COVID-19).

Financial Services Authority Regulation has been in effect from March 13, 2020 to March 31, 2021, in accordance with Article 10 of the Financial Services Authority Regulation Number 11 / POJK.03 / 2020 concerning National Economic Stimulus as a Countercyclical Policy on the Impact of the Spread of Coronavirus Disease 2019, that: This Financial Services Authority Regulation has been in effect from March 13, 2020 to March 31, 2021, in accordance with Article 10 of the Financial Services Authority Regulation Number $11 /$ POJK.03 / 2020 concerning National Economic Stimulus as a Countercyclical Policy on the Impact of the Spread of Coronavirus Disease 2019, that.

The Financial Services Authority (OJK) provides leniency or relaxation for micro and small business loans for a value below IDR 10 billion, both credit / financing provided by banks and the non-bank financial industry to debtors. What is meant by debtors who are affected by the spread of covid-19 including micro, small and medium business debtors are debtors who experience difficulties in fulfilling obligations to banks because the debtor or debtor's business is affected by the spread of Covid-19, either directly or indirectly in the economic sector between others tourism, transportation, hospitality, trade, processing, agriculture and mining. As an example:

a. Debitors who have been affected by the closure of transportation and tourism routes from China to other countries that have been affected by Covid-19 as well as warnings of tourist visits from several countries.

b. Debitors who were affected by a significant decrease in the volume of export and import due to supply chain linkages and trade with China and other countries that have been affected by Covid -19 .

c. Debtors who are affected by the obstruction of infrastructure development projects due to the interruption of the supply of raw materials, labor and machinery from China and other countries.

The credit relaxation policy for debtors affected by the spread of Covid-19 who have difficulty fulfilling obligations to banks, needs other steps or policies that need to be aligned, meaning that the credit relaxation policy cannot be implemented just like that, there is a need for rules. Other regulations such as one related to agreements that have been arranged or have been made between the bank (creditor) as the credit provider and the customer as the credit recipient (debtor). In the legal basis of the agreement itself is regulated in Article 1313 of the 
Civil Code states that: "An agreement is an act in which one or more people bind themselves to one or more other people.". Faisal Santiago, said that: "An agreement is a legal event in which two or more people promise each other to do or not do a certain act and it is done in writing.".

In implementing the agreement, the parties who have bound themselves must carry out what has been agreed upon and what has become their obligation in the agreement. The obligation to carry out what was agreed upon is called achievement. However, during the Covid-19 pandemic, even though there was a credit relaxation policy, the debtor still could not fulfill or carry out what had been agreed upon, it was considered default, this would be detrimental to the debtor. In this case, it is necessary to formulate policies carried out by banks, in order to create harmony and balance in viewing an agreement they make. In this regard, it is necessary to see or study the legal aspects contained in force majeure. Force majeure is a condition where a debtor is prevented from carrying out his performance due to unexpected circumstances or events at the time the contract was made, the condition or event cannot be accounted for to the debtor, while the debtor is not in bad faith.

\section{Problem Statement}

Based on the above problems, the formulation of this study is whether the relaxation of credit provided by banks during the Covid 19 Pandemic did not deviate from the force majeure aspect?

\section{Literature Review}

\subsection{Credit Relaxation}

Credit relaxation is an improvement effort made in lending activities for debtors who have the potential to experience difficulties in fulfilling their obligations. According to Hermansyah, what is meant by restructuring is:

"There are two ways to settle non-performing loans, namely through credit rescue and credit settlement. Credit rescue is a step to resolve non-performing loans through re-negotiation between the bank (creditor) and the customer (debtor). Credit settlement is a step towards solving problem loans through legal institutions. Legal institutions in this case are the State Receivables Affairs Committee and the Directorate General of State Receivables and Auctions, judicial bodies, and arbitration or alternative dispute resolution bodies.".

Regarding the rescue of non-performing loans, it can be carried out by referring to Article 1 number 26 of Bank Indonesia Regulation Number 14/15 / PBI / 2012 concerning Asset Quality Assessment for Commercial Banks, before being resolved through legal institutions, namely through alternative handling: Credit Restructuring is an effort made by the Bank in lending activities for debtors experiencing difficulties in fulfilling their obligations, which are carried out, among others, through:

a. reduction in Credit interest rates;

b. extension of the Credit term;

c. reduction in arrears Credit interest;

d. reduction in arrears of Credit principal;

e. additional Credit facilities; and / or 
f. conversion of Credit to Temporary Equity Participation.

The government has issued a restructuring policy, the Covid-19 period through the Financial Services Authority Regulation Number 11 / POJK.03 / 2020 concerning National Economic Stimulus as a Countercyclical Policy on the Impact of the Spread of Coronavirus Disease 2019. The provisions of Article 5 stipulate that:

1. The quality of restructured credit or financing is determined to be current since the restructuring is carried out.

2. Credit or financing restructuring as referred to in paragraph (1) can be carried out on credit or financing provided before or after the debtor is affected by the spread of coronavirus disease 2019 (COVID-19) including micro, small and medium business debtors.

3. Credit for a BPR or financing for a restructured BPRS is exempted from the application of the accounting treatment for credit or financing restructuring.

The restructuring policy must fulfill the requirements stipulated in Article 6 of the Financial Services Authority Regulation Number 11 / POJK.03 / 2020 concerning National Economic Stimulus as a Countercyclical Policy on the Impact of the Spread of Coronavirus Disease 2019, that: The provisions referred to in Article 5 apply to credit or financing that meets the requirements: (1) given to debtors affected by the spread of coronavirus disease 2019 (COVID-19) including micro, small, and medium business debtors; and (2) restructured after debtors were affected by the spread of coronavirus disease 2019 (COVID-19) including micro, small and medium business debtors.

Requirements for applying for credit restructuring to banks, namely debtors who experience difficulties in paying principal and / or loan interest and the debtor has good business prospects and is considered capable of fulfilling obligations after the credit is restructured. The details of the terms \& conditions regulated by the Financial Services Authority Regulation Number 11 / POJK.03 / 2020 concerning the National Economic Stimulus as a Countercyclical Policy on the Impact of the Spread of Coronavirus Disease 2019, are as follows:

a. Granting restructuring to debtors in the form of extending the credit / financing period for a maximum period of 1 year ( 12 months) and / or reducing interest rates.

b. That the debtor was directly affected by Covid-19 with a credit / financing value below Rp. 10,000,000,000.00 - (ten billion rupiah).

c. Whereas the debtor is an informal worker and / or UMKM entrepreneur.

d. That the debtor has no arrears before March.

Regarding the planning and implementation of debt restructuring, according to Johanes Ibrahim, he said: "basically, it depends on the agreement between the debtor and the creditor in preparing the debt payment agreement. There is not a single statutory provision that specifies in detail the methods debtors and creditors must implement in implementing debt restructuring. In practice, various types of debt restructuring implementation methods are widely used by the public.

The simplest method of debt restructuring to be implemented is by rescheduling or rescheduling, which is a change in credit terms which only concerns changes in the payment term. By rescheduling their debt repayments, creditors provide concessions to debtors to pay their debts that are due by postponing the due date. If the payment is made in installments, the creditor prepares a new loan installment schedule, where the amount of the payment obligation for each installment can be adjusted to the development of the debtor's financial liquidity. Thus, it is hoped that the debtor will be able to pay off outstanding debts without sacrificing the smooth running of his company's business. 
According to Muhamad Djumhana, the restructuring implementation method is: Realignment or restructuring, namely changes in credit terms, which include: (1) Additional funds; (2) Conversion of all or part of the outstanding debt into new principal; (3) Rescheduling or return requirements.

In carrying out debt restructuring, many things must be considered and considered so that the main objective of providing a settlement that is beneficial to all parties can be fulfilled. What must be prioritized is building trust and mutual understanding between creditors and debtors themselves, which is very important because in carrying out debt restructuring, there must be one party who feels aggrieved so the trust factor is very important, without this the settlement mechanism will be very difficult. done.

\subsection{Force Majeure}

In Indonesian law, the legal basis for agreement is the Civil Code (BW), the articles related to force majeure are contained in Article 1244 of the Civil Code and Article 1245 of the Civil Code. Article 1244 of the Civil Code states: "The debtor must be punished to reimburse costs, losses and interest, if he cannot prove that the agreement was not carried out or was not timely in carrying out the engagement due to one thing.". Article 1245 of the Civil Code states: "There is no compensation for fees, losses and interest, if in a coercive situation or because of something that happens by chance, the debtor is prevented from giving or doing something that is required, or from carrying out an act which is prohibited for him.".

Article 1244 and Article 1245 regulate the same thing, namely the release of the debtor from his obligations. Force majeure is a condition that occurs after an agreement is made that prevents the debtor from fulfilling his performance. In this case the debtor cannot be blamed and does not have to bear the risk and cannot predict the occurrence of such a thing at the time the agreement is made. According to the opinion of experts related to force majeure, among others:

According to Subekti, he stated that: "A state of coercion (overmacht or force majeure) is the failure to carry out what was agreed upon due to things that are completely unpredictable, and where he cannot do anything about circumstances or events that arise out of his expectations. In other words, the non-fulfillment of the agreement or the delay in carrying it out, was not due to his negligence. He cannot be said to be one or negligent, and a person who is not wrong should not be subjected to the sanctions imposed for his negligence.".

According to Abdulkadir Muhammad, said that: "force majeure is a condition where achievements are not fulfilled by the debtor due to an event which cannot be known or can't be expected to occur when making the engagement. In a coercive situation, the debtor cannot be blamed because this situation arises beyond the willingness and ability of the debtor". Force majeure due to unforeseen events can be due to something that is beyond the control of the debtor, which condition can be used as a reason to be exempted from the obligation to pay compensation. According to Mariam Darus Badrulzaman, the forceful situation resulted in the engagement no longer working even though the bond itself still existed, in this case:

a. The creditor cannot demand that the agreement be fulfilled;

b. It cannot say that the debtor is in a state of neglect and therefore cannot sue.

c. Creditors cannot request termination of the agreement.

d. In a reciprocal agreement, the obligation to do a counter-achievement is canceled.

In principle, the bond remains and what disappears is only its working power. That the bond still exists, it is important in a temporary, coercive situation. The bonding returns to work 
power when the coercive circumstances cease. The things that need to be known in connection with this force are:

1. The debtor can state that there is a compelling situation by way of deterrence (exception)

2. Based on the position of the judge, he cannot reject a lawsuit based on coercive circumstances, the debtor bears the burden of proving the existence of a coercive situation.

In the history of thinking about the state of force there are 2 (two) schools or teachings, namely: (1) de objective overmarchtsleer or absolute; (2) de subjectieve overmachtsleer or relative. Based on these two teachings, it can be explained as follows :

a. De objective overmarchtsleer or absolut. According to the absolute coercive situation, the debtor is in a state of compulsion, if the achievement of the achievement is not possible (there is an element of impossibility) to be carried out by anyone or by everyone. In this teaching the scholars are focused on natural disasters or major accidents, so that in such circumstances anyone cannot fulfill their achievements. If the goods are destroyed or lost outside of trade is considered a condition of force.

b. De subjectieve overmachtsleer or relatif. According to the teaching of a subjective (relative) coercive situation, there is a situation of coercion, if the debtor is still possible to make achievements, but practically with great difficulty or sacrifice (there is an element of difficulty), so that in such a situation the creditor cannot demand achievement.

In order for the debtor to state that there is a compelling situation based on one of the things mentioned above, according to Mariam Darus Badrulzaman, 3 (three) conditions must be fulfilled, namely: (1) he must prove his innocence; (2) he cannot fulfill his obligations otherwise; (3) he does not bear the risk according to the provisions of the law or the provisions of the agreement or because of the teaching of good faith must bear the risk.

\section{Research Methods}

The method used in this research is normative research or also known as literature law research is: "Legal research is carried out by examining library materials or mere secondary data". The data used in this research is secondary data, namely data whose sources are obtained from literature review and carried out by making an inventory of all regulations and data that are related to the object of research obtained from: primary legal materials, secondary legal materials and tertiary legal materials, namely materials that provide explanation of primary legal materials and secondary legal materials in the form of dictionaries and encyclopedias.

\section{Analysis and Discussion}

Loan restructuring is important to reduce the economic burden of people affected by the Covid-19 pandemic in 2020. The government and OJK have issued a credit restructuring policy in early March 2020 as a measure to anticipate the impact of Covid-19. Therefore, the government through the Financial Services Authority (OJK) has provided credit payment relief in the midst of the Covid-19 pandemic, through the Financial Services Authority Regulation Number 11 / POJK.03 / 2020 concerning National Economic Stimulus as a Countercyclical Policy on the Impact of the Spread of Coronavirus Disease 2019. But related 
In this policy, there are other rules that govern a credit agreement wherein an agreement is a legal rule that must be obeyed or broken by the parties making the agreement. In an agreement there is such a thing as the principle of freedom of contract, which is a principle that gives freedom to the parties to enter into an agreement and becomes the legal basis for the parties who enter into the agreement, this is in accordance with the provisions of Article 1338 paragraph (1) of the Civil Code which reads "All agreements that are legally made are valid as laws for those who make them". Faisal Santiago explained that in the principle of freedom of contract is a principle that gives freedom to the parties to:
a. Make or not make an appointment
b. Make agreements with anyone.
c. Determine the contents of the agreement, implementation, and requirements;
d. Determine the form of the agreement, namely written or oral.

The principle of freedom of contract is the most important principle in the agreement because in addition to regulating the agreement as a law for them (for the parties) who made it, in this principle there is also an expression of human rights in making an agreement and providing opportunities for development. legal agreement. In the contents of the agreement, clauses are made in that clause, usually stipulating the existence of clauses regarding force majeure. Whether in the force majeure clause there is a Covid-19 pandemic or not, if there is no force majeure is not fulfilled. This force majeure usually contains arrangements for things that may occur in the future that could potentially lead to conflict between the parties to the agreement. In the force majeure, there are three elements that must be fulfilled, namely not full of achievements, there are reasons that lie outside the debtor's error and the causative factor was not previously suspected and cannot be accounted for to the debtor. Force majeure can be interpreted as a condition in which a debtor is prevented from carrying out his performance because of an unexpected situation or event at the time the agreement was made, the condition or event cannot be accounted for to the debtor, while the debtor is not in a bad faith situation.

Force majeure events are often associated with an event caused by a greater force, usually in the form of earthquakes, floods, volcanic eruptions (acts of god), war, riots, government actions, terrorist acts. Based on the examples of these events, the Covid-19 pandemic is also included in force majeure because the disaster or virus that hit Indonesia, even the world was an unexpected event and resulted in obstruction or obstruction of the debtor's achievement in fulfilling his obligations to the bank. or other financial services.

This Covid-19 pandemic, including the force majeure aspect, which refers to the provisions of Article 1245 of the Civil Code, states that: there are no changes in fees, losses and interest, if in a compulsive situation or because of something that happens by chance, the debtor is prevented from giving or doing something that is required, or perform an act that is forbidden to him. So the Covid-19 pandemic is included in a force majeure, because the Covid-19 pandemic happened by chance that hit Indonesia and even the world, so that due to the Covid-19 pandemic, it had a big impact on the country, especially in the economic sector. The economy is experiencing sluggish growth, many buying and selling trading activities have stopped. This results in the debtor being unable to fulfill his obligation to pay credits beyond his means. Credit relaxation policy by the Financial Services Authority, by conducting credit restructuring by the Bank, with efforts to improve credit activities for debtors experiencing difficulties in fulfilling their obligations, which include: lowering credit interest rates, extending credit terms, reducing interest arrears credit, reduction of loan principal arrears, additional credit facilities; and / or and credit conversion to temporary equity participation.

The credit restructuring policy has deviated from the legal aspects contained in Article 1245 of the Civil Code regarding force majeure. So as a result of this force majeure, the 
creditor cannot demand that the agreement be fulfilled, cannot be declared in a negligent state and cannot sue and the creditor cannot request termination of the agreement. Performance fails (in a reciprocal agreement) and the debtor is not required to fulfill performance temporarily or there is a new agreement. In principle, an engagement will be terminated and therefore will free the debtor from his obligations by one of the 10 (ten) ways to cancel the engagement as regulated in Article 1381 of the Civil Code. However, the existence of force majeure does not automatically cancel the debtor's obligations. The provisions of Article 1245 of the Civil Code, only relate to the release of the obligation to compensate for damages. Therefore, at the time of filing a force majeure claim, the debtor must prepare alternative changes to the agreement, for example in the form of changes in credit / financing payment deadlines, adjustments to quantity, quality of goods / services, contract milestones and service delivery time schedules. Real or unexpected changes in circumstances must be taken into account in implementing the agreement. If it is agreed between the creditor and the debtor, the amendment to the agreement is better stated in a notarial deed and becomes an inseparable part of the original agreement. So it is necessary to do it in deliberation and remain subject to the procedures for dispute resolution stipulated in the agreement and the realization of the principle of balance, namely the principle that requires both parties to fulfill and implement the agreement. In negotiating the amendment of the agreement, the parties should as much as possible prioritize deliberative settlement and avoid settlement through litigation. In the current situation, dispute resolution through litigation is not only a lengthy but also complex process. It can be imagined, how many potential cases of default due to the COVID-19 pandemic will be resolved in court especially in the current situation of physical distancing restrictions.

\section{Conclusion}

The Financial Services Authority's policy through the Financial Services Authority Regulation Number 11 / POJK.03 / 2020 concerning National Economic Stimulus as a Countercyclical Policy on the Impact of the Spread of Coronavirus Disease 2019, which should aim to encourage optimization of banking performance, especially the intermediation function, maintain financial system stability, and support growth economic stimulus policy needs to be taken as a countercyclical impact of the spread of the coronavirus disease 2019 (COVID-19). However, the credit restructuring policy has deviated from the legal aspects contained in Article 1245 of the Civil Code regarding force majeure. In conducting credit restructuring it is necessary to have deliberation between creditors and debtors, in order to realize the principle of balance and not to deviate from the force majeure aspects contained in Article 1245 of the Civil Code.

\section{References}

[1] Badrulzaman, Mariam Darus, Kompilasi Hukum Perikatan, Bandung : Citra Aditya Bakti, 2016.

[2] Djumhana, Muhamad, Hukum Perbankan di Indonesia, Bandung : Citra Aditya Bakti, 2012.

[3] Hermansyah, Hukum Perbankan Nasional Indonesia. Yogyakarta : Prenada, 2008. 
[4] Ibrahim, Johanes, Cross Default \& Cross Collateral Sebagai Upaya Penyelesaian Kredit Macet, Bandung : Refika Aditama, 2004.

[5] Kitab Undang-Undang Hukum Perdata.

[6] Muhammad, Abdulkadir, Hukum Perdata Indonesia, Bandung : Citra Aditya Bakti, 2014.

[7] Santiago, Faisal, Pengantar Hukum Bisnis, Jakarta : Mitra Wacara Media, 2012.

[8] Soekanto, Soejono, Pengantar Penelitian Hukum, Jakarta : Universitas Indonesia, 2014.

[9] Subekti, Hukum Perjanjian, Jakarta : Intermasa, 2002.

[10] Peraturan Bank Indonesia Nomor 14/15/PBI/2012 tentang Penilaian Kualitas Aset Bank Umum.

[11] Peraturan Otoritas Jasa Keuangan Nomor 11/POJK.03/2020 tentang Stimulus Perekonomian Nasional Sebagai Kebijakan Countercyclical Dampak Penyebaran Coronavirus Disease 2019. 